\title{
POPULATION DYNAMICS OF Notopterus notopterus (Pallas, 1769) FROM THE KAPTAI RESERVOIR OF BANGLADESH
}

\author{
M. Golam Mustafa ${ }^{* 1}$, S. Singha ${ }^{1}$, M. R. Islam ${ }^{1}$ and Nayan Mallick ${ }^{2}$ \\ Noakhali Science and Technology University (NSTU), Sonapur-3814, Noakhali, Bangladesh
}

\begin{abstract}
Population parameters of Notopterus notopterus (Pallas, 1769) from length-frequency data collected from Kaptai Reservoir of Rangamati, Bangladesh from January, 2013 to December, 2013 were calculated by using FiSAT software. The asymptotic total length $\left(L_{\infty}\right)$ and growth coefficient $(K)$ were estimated to be $34.91 \mathrm{~cm}$ and $0.38 y^{-1}$ respectively. The instantaneous rate of natural mortality $(M)$, fishing mortality $(F)$ and total mortality $(Z)$ were estimated to be as $0.91 y^{-1}, 0.28 y^{-1}$ and $1.19 y^{-1}$ respectively. The value of exploitation rate $(E)$ was found to be 0.24 which clearly pointed toward moderate or less fishing pressure $(E<0.50)$ of $N$. notopterus in the Kaptai reservoir of Bangladesh. The recruitment of the species was found throughout the year with two peaks - one from March-April; and another from May- June. Virtual population analysis (VPA) estimated that the maximum numbers of $N$. notopterus were caught between $10.50 \mathrm{~cm}$ to $32.50 \mathrm{~cm}$ with maximum $F$ value $\left(0.80 \mathrm{y}^{-1}\right)$ in the mid length of $18.30 \mathrm{~cm}$. During the year 2013 the total catch of $N$. notopterus was found to be $664.5 \mathrm{MT}$, which contributed about $7.78 \%$ of the total catch of Kaptai Lake. Relative yield per recruit $\left(Y^{\prime} / R\right)$ and biomass per recruit $\left(B^{\prime} / R\right)$ suggested that the natural mortality should be reduced to $0.91 y^{-1}$ by proper management to obtain a maximum sustainable exploitation rate $\left(E_{\max }=0.828\right)$ for the species in the reservoir.
\end{abstract}

Key words: Asymptotic length, Growth coefficient, Mortality, Virtual Population Analysis, Recruitment pattern, Exploitation rate, Notopterus notopterus

\footnotetext{
* Corresponding author email: mustafa.nstu2013@gmail.com

${ }^{1}$ Noakhali Science and Technology University (NSTU), Sonapur-3814, Noakhali, Bangladesh

${ }^{2}$ Institute of Marine Science and Fisheries, University of Chittagong, Chittagong-4331, Bangladesh
}

Received: 14.05.2014 


\section{INTRODUCTION}

Notopterus notopterus (Pallas, 1769) is a member of the family Notopteridae, commonly known as grey featherback and bronze featherback but locally known as Foli and Pholoi in Bangladesh. This species is locally important for its taste and abundance in the Kaptai reservoir. Kaptai Lake, located at Kaptai Upazila in Rangamati district of Bangladesh, is the spawning, nursing and feeding ground of many important fishes. During the last couple of decades availability of this fish in the Reservoir environment has been drastically declined due to several factors, such as siltation caused by deforestation, over fishing, indiscriminate killing of supplemental fingerlings and use of various types of destructive fishing methods (Ahmed and Hambrey, 1999). Effective management of any fishery requires considerable knowledge on population parameters such as length-weight relationship, age and growth, mortality, recruitment pattern and stock position of important species. Estimation of these parameters leads towards the better prediction on fish stock assessment from which fisheries managers can know about the present status of any fishery. Without the information of these parameters, it is not possible to undertake an effective management program for a certain fishery. So, the population dynamics study will give an idea about growth variations of $N$. notopterus in natural water and the need for supplemental stocking if required. To calculate the maximum sustainable yield (MSY) it is also necessary to study the growth parameters in advance. Therefore, the present research was aimed to determine the population parameters of $N$. notopterus using length-frequency based analysis collected from Kaptai reservoir of Rangamati, Chittagong, Bangladesh.

\section{MATERIALS AND METHOD}

\section{Experimental Fish}

Experimental fish of this research work was Notopterus notopterus (Pallas, 1769).

\section{Study Area}

The study area of this research work was Kaptai reservoir $\left(22^{\circ} 29^{\prime} 45^{\prime \prime} \mathrm{N}\right.$ and $\left.92^{\circ} 13^{\prime} 45^{\prime \prime} \mathrm{E}\right)$ of Rangamati, Chittagong, Bangladesh which is the largest man-made freshwater body in Bangladesh with a total surface area of 68,800 hectare and average water depth is about 9 meters with maximum depth of 32 meters.

\section{Sampling Station}

The selected sampling stations for this research work were fish landing centre of Bangladesh Fisheries Development Corporation (BFDC) and local markets (Natun Bazar, Jetty Ghat Bazar) near Kaptai reservoir

\section{Collection of Data}

Total 555 raw fish samples were collected for one year from January 2013 to December 2013. Samplings were done monthly at a regular interval directly from 
the BFDC fish landing centre and local fish markets (Natun Bazar, Jetty Ghat Bazar) of Rangamati district. These fish samples were collected by the fishermen from Kaptai Lake using gill net and lift net. In case of gill netting, the fishermen used a wide range of mesh sizes $(6-14 \mathrm{~cm})$.

\section{Data Processing and Analysis}

\section{A. Estimation of Asymptotic Length $\left(L_{\infty}\right)$ and Growth Coefficient $(K)$}

Month-wise length frequency distribution data were used to estimate the total asymptotic length $\left(L_{\infty} \mathrm{cm}\right)$ and growth coefficient $(K$ year-1) of the Von Bertalanffy growth equation (Bertalanffy, 1938; Beverton and Holt, 1957). The ELEFAN I and ELEFAN II routines incorporated in FiSAT (FAO ICLARM Stock Assessment Tools) software (Gayanilo and Pauly, 1997) were used to determine $L \infty$ and $K$ value following the Powell-Wetherall method (Wetherall et al., 1987). This method was used to provide an initial estimate of $L_{\infty}$. This initial estimate of $L_{\infty}$ was then used as seed value to determine the value of $K$ (Silvestre and Garces, 2004). Minor adjustments to $L_{\infty}$ and $K$ were made to maximize the "goodness of fit" criterion built into ELEFAN I (Pauly, 1987). This led to a preliminary estimate of $L_{\infty}$ and $K$ that were used to obtain "probabilities of capture" by length class using the routine in FiSAT. These "probabilities of capture" were used to correct the length frequency distribution data to account for incomplete selection and recruitment and the final estimates of $L_{\infty}$ and $K$ were obtained by using these corrected length distribution data through ELEFAN I(Silvestre and Garces, 2004). ELEFAN I was used to estimate the growth parameters based on the Von Bertalanffy Growth Formula (VBGF) expressed in the form (Pauly and Gaschutz, 1979):

$$
L_{t}=L_{\infty}\left(1-\exp \left[-K\left(t-t_{0}\right)\right]\right)
$$

Where, $\mathrm{L}_{\mathrm{t}}$ is the predicted lengths at age t. $\mathrm{L}_{\infty}$ is the asymptotic length or mean length of a given stock of fish. $\mathrm{K}$ is a growth constant, also called "stress factor" by Pauly (1980), $\mathrm{t}_{\mathrm{o}}$ is the "age" the fish would have been at zero length.

\section{Mortality Estimation}

In FiSAT software (Gayanilo and Pauly, 1997) package, ELEFAN II was used to estimate the total mortality coefficient, $Z(y-1)$ using the length-converted catch curve by means of the final estimates $L_{\infty}$ of $K$ and the length frequency distribution data (Beverton and Holt, 1957; 1966) for the species N. notopterus. The rate of natural mortality $M(y-1)$ for each species was estimated using Pauly's empirical equation.

$$
\ln [M]=-0.0152-0.279 \ln [L \infty]+0.6543 \ln [K]+0.463 \ln [T]
$$

This formula was used to obtain the estimate of $M$, given $\mathrm{L}_{\infty}$ (total length in $\mathrm{cm}$ ), $\mathrm{K}$ (the growth constant), and $\mathrm{T}$ (the mean environmental temperature $\mathrm{C}^{0}$ ). 
Once $\mathrm{Z}$ and $\mathrm{M}$ were obtained and then fishing mortality $(\mathrm{F})$ was derived from the relationship:

$F=Z-M$ (Silvestre and Garces, 2004)

And the exploitation rate (E) was obtained by the relationship:

$E=F / Z=F /(F+M)($ Beverton and Holt, 1966; King, 1995)

\section{Probability of Capture}

Probability of capture calculated from the length-converted catch curve routine was used to estimate the final values of $L_{25}, L_{50}$ and $L_{75}$ (i.e. lengths at which $25 \%$, $50 \%$ and $75 \%$ of the fish would be vulnerable to the gear such as seine net, cast net and gill net of specific mesh size) (Pauly, 1984).

\section{Recruitment Pattern}

Recruitment pattern was obtained by the backward projection of the frequencies onto the time axis of a time-series of samples along a trajectory defined by the Von Bertalanffy growth equation (Moreau and Cuende, 1991). This routine reconstructs the recruitment pulses from a time series of length-frequency data to determine the number of pulses per year and the relative strength of each pulse (Gayanilo et al., 2005).

\section{Virtual Population Analysis (VPA)}

Terminal population $\left(N_{t}\right)$ was estimated from $N_{t}=C_{t}\left(M+F_{t}\right) / F_{t}$ where, $C_{t}$ is the terminal catch and $F_{t}$ is the terminal Fishing Mortality and $M$ is the Natural Mortality. Starting from $N_{t}$, successive values of $F$ were estimated by iteratively solving $C_{i}=N_{i}+\Delta t\left(F_{i} / Z_{i}\right)\left(\exp \left(Z_{i} \Delta t_{i}\right)-1\right)($ Gayanilo et al., 2005)

Where, $C_{i}=$ catch (in number) for a population during a unit time period $i$

$\Delta t_{i}=\left(t_{i+1}-t_{i}\right)$, and

$t_{i}=\left[t_{0}-(1 / K) \ln \left(1-\left(L_{i} / L_{\infty}\right)\right)\right]$.

The population sizes $\left(N_{i}\right)$ was computed from $N_{i}=N_{i+\Delta t_{i}} \exp \left(Z_{i}\right)$. The last two equations were used alternatively until the population sizes and fishing mortality for all length groups have been computed (Jones and Zalinge, 1981; Moreau and Cuende, 1991).

\section{Relative Yield-per-Recruit and Biomass-per-Recruit}

Relative yield-per-recruit (Y/R) was computed using the following formula (Gayanilo and Pauly, 1997; Beverton and Holt, 1966):

$$
\frac{Y}{R}=E U m\left(1-\frac{3 U}{(1+m)}+\frac{3 U^{2}}{(1+2 m)}-\frac{U^{3}}{(1+3 m)}\right.
$$


Where, $\mathrm{U}=1-\left(\mathrm{Lc} / \mathrm{L}_{\infty}\right), \mathrm{m}=(1-\mathrm{E}) /(\mathrm{M} / \mathrm{K})=\mathrm{K} / \mathrm{Z}, \mathrm{L}_{\mathrm{c}}=$ length of fish at first capture i.e. length at which 50 percent of the fish are retained by the gear $\left(\mathrm{L}_{50}\right)$ and $\mathrm{E}=\mathrm{F} / \mathrm{Z}$.

Relative biomass-per-recruit $(B / R)$ was estimated from the relationship $B / R=(\mathrm{Y} / \mathrm{R}) / \mathrm{F}$ (BOBP, 1985).

The value of $\mathrm{E}_{\max }, E_{0.1}$ and $E_{0.5}$ were estimated by using the first derivative of this function, where, $E_{\max }=$ maximum sustainable exploitation rate, $E_{0.1}=$ exploitation rate at which the marginal increase of relative yield-per-recruit is $1 / 10^{\text {th }}$ and $E_{0.5}=$ value of $\mathrm{E}$ under which the stock has been reduced to $50 \%$ of its unexploited biomass.

\section{RESULTS AND DISCUSSION}

\section{Asymptotic Length $\left(L_{\infty}\right)$ and Growth Coefficient $(K)$}

The minimum and maximum total lengths of $N$. notopterus (Pallas, 1769) were varied between $10.00 \mathrm{~cm}$ and $33.25 \mathrm{~cm}$ with the estimated value of asymptotic length $(L \infty) 34.91 \mathrm{~cm}$ which is higher than the value $(33.8 \mathrm{~cm})$ found by Kiran et al. (2004) and Sani et al. (2010); lower than the value $(40 \mathrm{~cm})$ found by Parameswaran and Sinha (1966). The value of Growth Coefficient $(K)$ was $0.38 \mathrm{yr}^{-1}$ for $N$. notopterus which were higher than the value $\left(0.35\right.$ year $\left.^{-1}\right)$ found by Amin et al. (2006) and lower than the value (1.6 $\left.\mathrm{yr}^{-1}\right)$ found by Zafar et al. (1998).

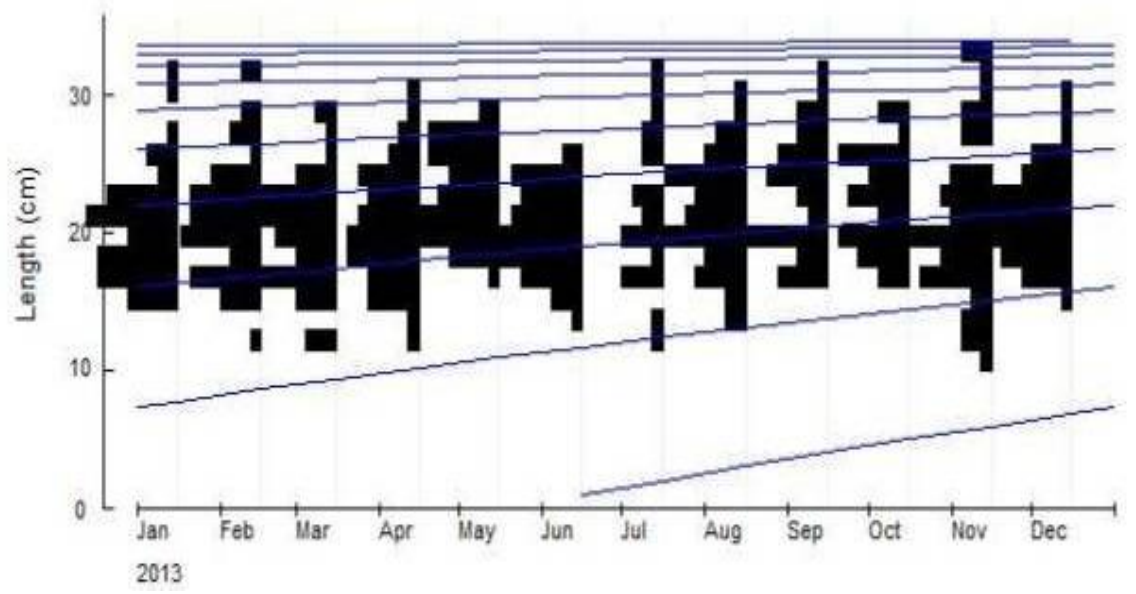

Figure1: Length-frequency distribution of $N$. notopterus in different months with superimposed growth curves as obtained from K-scan of FiSAT $(n=555)$.

\section{Mortality (Total, Natural and Fishing) and Exploitation Rate}

The values of total mortality $(Z)$, natural mortality $(M)$ and fishing mortality (F) were $1.19 y-1,0.91 y-1$ and $0.28 y-1$ respectively (Figure 2); of which natural mortality was dominated over the fishing mortality which indicate that low fishing pressure is prevailing for $N$. notopterus in the Kaptai reservoir. The similar result was 
reported by Dinh, et al. (2007) for goby (Pseudapocryptes elongates) in the coastal mud flat areas of the Mekong Delta, Vietnam whereas different results were calculated by Nabi, et al. (2007) for Polynemus paradiseus and Rahman and Haque (2008) for Gudusia chapra. An exploitation level (E) of 0.24 was obtained for the $N$. notopterus fishery in Kaptai reservoir (Figure 2) which was relatively lower than the optimum fishing level (0.5) indicating lower level of exploitation rates of $N$. notopterus from this reservoir. The same phenomenon was reported by Azadi et al. (1997) for Gudusia chapra and Gudusia manminna of the Kaptai reservoir where lower level of exploitation rate was observed.

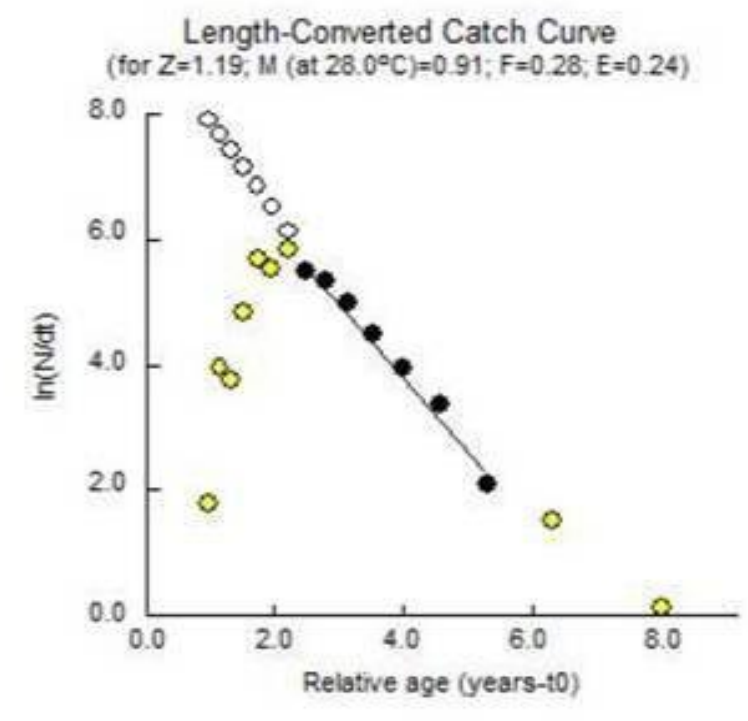

Figure 2: Length-converted catch curve for $N$. notopterusthat was used for estimating different mortalities and exploitation rate $(n=555)$.

\section{Probability of Capture}

The estimated length sizes for $25 \%\left(L_{25}\right), 50 \%\left(L_{50}\right)$ and $75 \%\left(L_{75}\right)$ probabilities of capture would be $16.83 \mathrm{~cm}, 18.33 \mathrm{~cm}$ and $19.83 \mathrm{~cm}$ respectively for $N$. notopterus (Figure 3 ) indicating high catching probability of the juveniles to the reservoir. From the probability of capture analysis, it was found that about $75 \%$ fish are caught at the length of $19.83 \mathrm{~cm}$ for $N$. notopterus which indicated a higher catching probability of the pre-matured fish in Kaptai reservoir catches. 


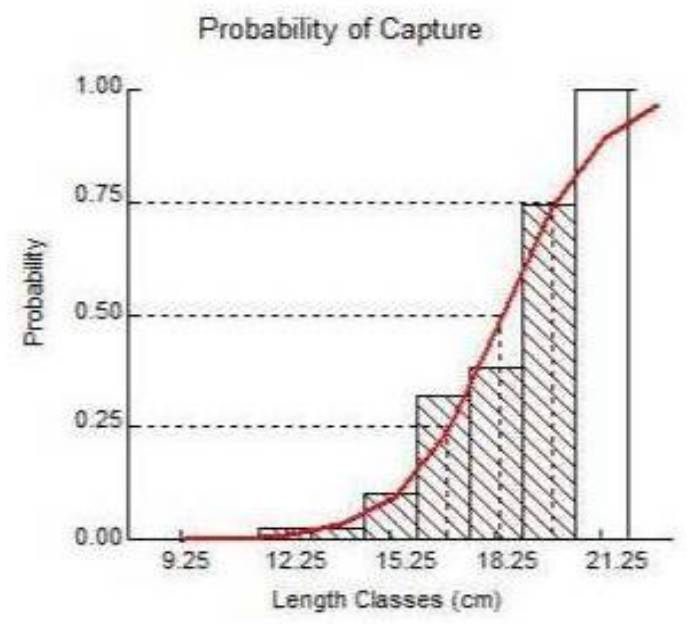

Figure 3: Probability of capture $(n=555)$

\section{Recruitment Pattern}

Two recruitment peaks were found for $N$. notopterus, one in March-April and another in May- June (Figure 4), with a continuous recruitment in almost every month in the reservoir. Two recruitment peaks for several fishes were reported by Rusell et al. (1977); Williams and Sale (1981); Fowler et al. (1992); Etim et al. (1994); Nabi et al. (2007).

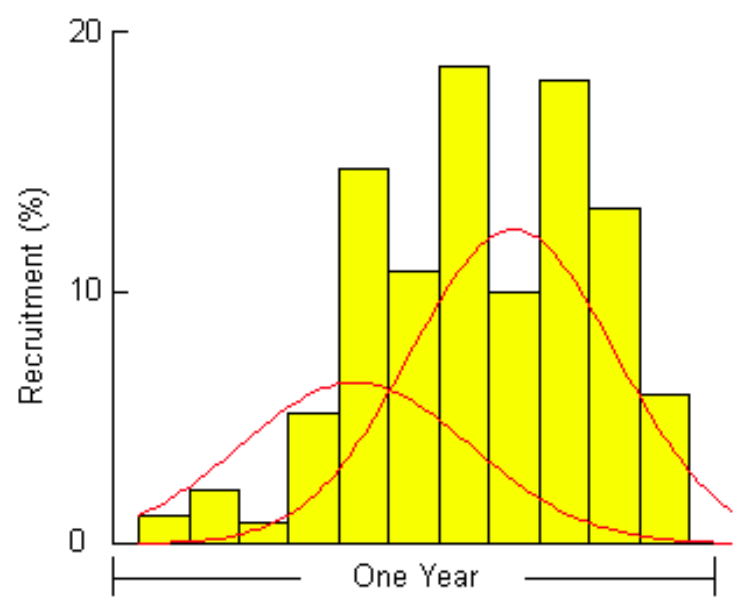

Figure 4: Recruitment patterns of $N$. notopterus for the investigated period $(n=555)$. 


\section{Virtual Population Analysis}

Total production in the year 2013 was 8537 MT (FRSS 2013) in Kaptai reservoir where 7310 MT (including $N$. notopterus) for other inland species excluding common available fishes.

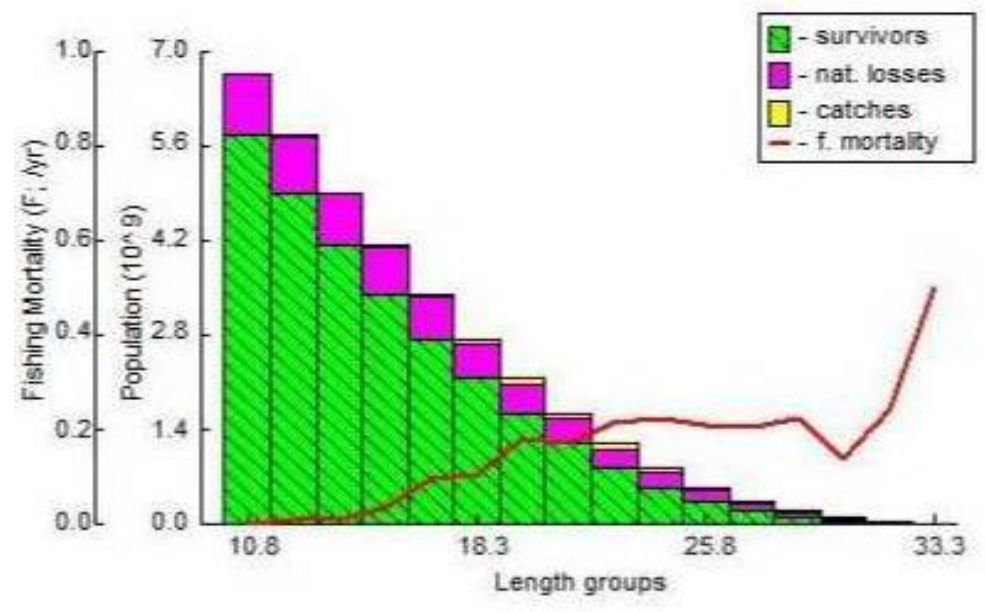

Figure 5: Population size and mortality Characteristics for $N$. notopterus $(\mathrm{n}=555)$ of Kaptai Lake based on length structured VPA.

The $\mathrm{F}$ at-length array showed (Figure 5) that the maximum fishing mortality is occurring in the length between $10.5 \mathrm{~cm}$ to $30.5 \mathrm{~cm}$ with a maximum value in the length of $33.25 \mathrm{~cm}$ that repeatedly indicates high fishing mortality in the juvenile $N$. notopterus of Kaptai reservoir due to fishing operation.

The total steady state biomass was found to be 664.5 MT. Fishing mortality significantly increases with increasing of body length.

\section{Relative Yield per Recruit and Biomass per Recruit}

Beverton and Holt's relative yield per recruit and average biomass per recruit models, showing levels of yield indices in the Figure 6 for N. notopterus in the Kaptai Lake.

Plot in relative yield per recruit $\left(Y^{\prime} / R\right)$ and biomass per recruit $\left(B^{\prime} / R\right)$ were determined as a function of $L_{c} / L_{\infty}$ and $M / K$ (Figure 6) respectively. The $E_{0.1}$ and $E_{0.5}$ values were found to be 0.707 and 0.364 respectively. The exploitation rate at $E=$ 0.24 (Figure 2) from the catch curve for $N$. notopterus was lower than that of generated $75 \%$ of $B^{\prime} / R\left(E_{0.1}=0.707\right)$ or maximum $Y^{\prime} / R\left(E_{\max }=0.828\right)$. This indicates that $\left(Y^{\prime} / R\right)$ could be increased slightly by increasing $E$. However, maximization of yields would lead to relatively low stock biomass, i.e. to low catch per effort. 


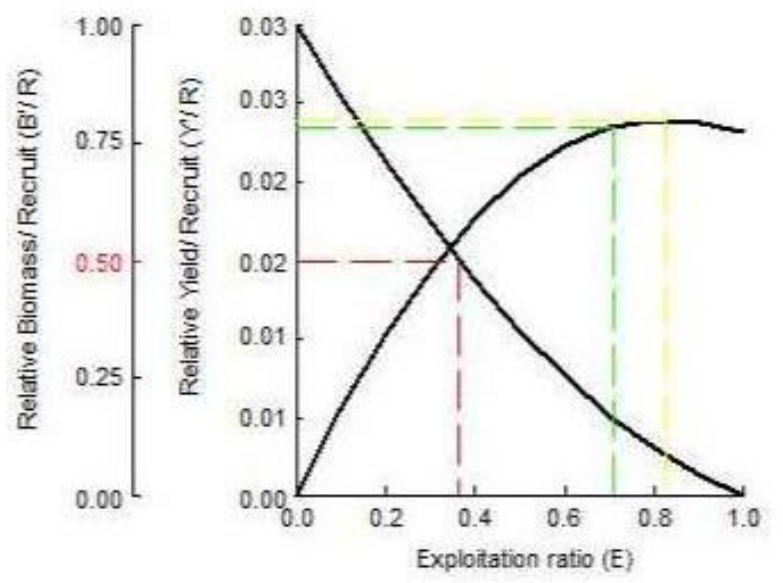

Figure 6: Relative yield per recruit and biomass per recruit for $N$. notopterus $(\mathrm{n}=555)$

\section{CONCLUSION}

Kaptai reservoir is considered safe from human activities and it is capable of supporting various fish species including $N$. notopterus. From the findings of the present study it can be concluded that the stock of $N$. notopterus is more or less under optimum exploitation level. Any major change in the existing fishing level/exploitation will most likely result in a reduction in the yield per recruit and thereby hamper the MSY. Therefore, protection from any over exploitation, prohibition of indiscriminate fishing with non-allowable mesh size gears/nets, banning of fishing particularly during the spawning season of the studied species are recommended, which in turn will help to manage this fishery in a more sustainable way.

\section{REFERENCES}

Ahmed, K. K. and Hambrey, J. B. 1999.Brush shelter: a recently introduced fishing method in the Kaptai reservoir fisheries in Bangladesh. Naga, the ICLARM Quarterly, 22(4):2023

Ahmed, K. K. U., Amin, S.M.N., Haldar, G. C. and Dewan, S. 2003. Population Dynamics and Stock Assessment of Catla catla (Hamilton) in the Kaptai reservoir, Bangladesh. Asian Fisheries Science, 16, pp. 121-131

Amin, S. M. N., Ara, R. and Zafar, M. 2006. Conservation of Marine and Coastal Shrimp Resources and Sustainable Aquaculture. Research Journal of Fish \& Hydro:1(1):18-22

Azadi, M. A., Mustafa, M. G. and Rahman, A. S. M. S. 1997. ELEFAN based population dynamics of two clupeids, Gudusia chapra (Hamilton) and Gonia losa manmina (Hamilton) from Kaptai reservoir, Bangladesh. Chittagong University Student Part II Section, 21(2):125-132 
Bertalanffy, L. V. 1983.A quantitative theory of organic growth. Human Biology, 10. pp.181213

Beverton, R. J. H. and Holt, S. J. 1966.Manual of Methods for Fish Stock Assessment, Part 2. In: Tables of Yield Functions, Fisheries Technical Paper No. 38. Food and Agriculture Organization of the United Nations, Rome, Italy, pp.7-29

Beverton, R. J. H. and Holt, S. J. 1957.On the Dynamics of Exploited Fish Populations. Fish. Invest. Ser. II., 19, pp. 5 - 33

Bay of Bengal Program (BOBP). 1985. Marine Small Scale Fisheries of Bangladesh: a general description, BOBP, Madras, India.

Chakma, I. L. 2007. Fish Culture in Hill Tract Regions, Desio Projatir Matshya Sakgrakkhon O Shamprasaran Ovijan 2007, Department of Fisheries, Ministry of Fisheries and Livestock, Dhaka, pp. 68

Dinh, T. D., Ambak, M. A., Hassan, A. and Phuong, N. T. 2007.Biology and population dynamics of the goby Pseudapocryptes elongatus in the coastal mud flat areas of the Mekong Delta, Vietnam. Pakistan Journal of Biological Sciences, 10(19): 3284-3294

Gayanilo, F. C. and Pauly, D. 1997. The FAO ICLARM Stock Assessment Tools (FiSAT): Reference Manual. Food and Agriculture Organization of the United Nations, Rome, Italy, pp. 15-42

Gayanilo, F.C., Sparre, P. and Pauly, D. 2005. FAO-ICLARM Stock Assessment Tools II (FiSAT II), User's Guide, Computerized Information Series (Fisheries) No. 8, (Revised Version), Food and Agriculture Organization of the United Nations, Rome, Italy

Jones, R. and Zalinge, N. P. V. 1981. Estimations of mortality rate and population size for shrimp in Kuwait Waters. Kuwait Bull ofMarine Science, 2: 273-288

Khan, MD.G. and Mustafa, MD. G. 1989. Length-frequency based population analysis of the threadfin bream Nemipterus japonicus of the Bangladesh coast. Indian Journal of Fisheries, 36(2):163-166

King, M.1995. Fisheries biology, assessment and management fishing news books, London, pp. 22-115

Moreau, J. and Cuende, F. X.1991.On improving the resolution of the recruitment patterns of fishes. Fishbyte, 9(1): 45-46

Mustafa, M.G. and Graaf, G. de. 2008. Population parameters of important species in inland fisheries of Bangladesh. Asian Fish Science, 21:147-158

Nabi, M. R. and Ullah, M. H. 2012.Effects of Set Bagnet fisheries on the shallow coastal ecosystem of the Bay of Bengal, Ocean \& Coastal Mgt, 67: 75-86

Nabi, M. R., Hoque, M. A., Rahman, R. A., Mustafa, S. and Kader, M. A. 2007. Population Dynamics of Polynemus paradiseus from Estuarine Set Bag Net Fishery of Bangladesh. Chiang Mai Journal of Science, 34(3): 355-365

Pallas, P. S. 1769. Spicilegia zoologica quibus novae imprimis et obscurae animalium species iconibus, descriptionibus atque commentariis illustrantur. 1(7):1-42 (Pls. 1-6)

Pauly D. 1984.Fish Population Dynamics in Tropical Waters: A Manual for Use with Programmable Calculators, Studies and Review No. 8, Manila, Philippines: International Center for Living Aquatic Resource Management 
Pauly, D. 1980. On the interrelationship between natural mortality, growth parameters and mean environmental temperature in 175 fish stocks. Journal of the CIEM, 39: 175-192

Pauly, D. A. 1987.Review of the ELEFAN System for Analysis of Length-Frequency Data in Fish and Aquatic Invertebrates. In: Pauly, D. and Morgan, G.R. eds., Length-Based Methods in Fisheries Research, Conference Proceedings, International Center for Living Aquatic Resource Management, Manila, Philippines, pp. 5-8

Pauly, D. and Gaschütz,G. 1979. A simple method for fitting oscillating length growth data, with a program for pocket calculators. International Council for the Exploration of the Sea, C.M. 1979/G: 24, pp. 26

Rahman, M. A. and Haque, M. M. 2008.Gonadal development of Gudusia chapra (Hamilton - Buchanan) from Rajdhala reservoir, Bangladesh. Journal Inland Fish Society, 40(1):10-15

Silvestre, G. T. and Garces, L. R. 2004. Population Parameters and Exploitation Rate of Demersal Fishes in Brunei Darussalam. Fish Research, 69:73-90

Wetherall,J. A.,Polovina, J. J. and Ralston, S. 1987. Estimating Growth and Mortality in Steady-State Fish Stocks from Length- Frequency Data. In: Pauly, D. and Morgan, G. R. eds., Length-Based Methods in Fisheries Research, Conference Proceedings, International Center for Living Aquatic Resource Management, Manila, Philippines, pp. $1-22$

Zafar, M., Mustafa, M. G. and Amin, S. M. N. 1998. Population dynamics of Acetes chinensis in the Kutubdia channel of Bangladesh coastal waters. Indian Journal of Fisheries, 45:121-127

Sani, R., Gupta, B.K., Sarkar, U.K. Pandey, A., Dubey, V.K., and Lakra, W.S. 2010. Lengthweight relationships of 14 Indian freshwater fish species from the Betwa (Yamuna River tributary) and Gomti (Ganga River tributary) rivers. Journal of Applied Ichthyology, PP. 1-4

Etim, L., Uwe-Bassey, B.U. Brey, T. 1994. Population dynamics of the West African croaker Pseudotolithus elongatus in the Cross River Estuary, Nigeria. Scientia Marina, 58 (4):315-321

Russell, B.C., Anderson, G.R.V. and Talbot, F.H. 1977. Seasonality and recruitment of coral reef fishes. Australian Journal of Marine and Freshwater Research, 28: 521-528

Fowler, A. J., Doherty, P. J. and Williams, D. McB. 1992. Multiscale analysis of recruitment of a coral reef fish on the Great Barrier Reef. Marine Ecology Progress Series, 82:131141

Williams, D. Mc. B., and Sale, P.F. 1981. Spatial and temporal patterns of recruitment of juvenile coral reef fishes to coral habitats within 'One-Tree Lagoon', Great Barrier Reef. Marine Biology, 65: 245-253

Kiran, B.R., Puttaiah, E.T. and Kumar, K. H. 2004. Length-weight relationship of Feather Back, Notopterus notopterus (Pallas) from Jannapura Pond, Karnataka, India. Zoos' Print Journal, 19(4):1449-1450 